\title{
Document Delivery Service update
}

\author{
By David A. Baldwin \\ Associate Director for Public Services \\ University of Wyoming
}

\author{
and Paul D. Dickey \\ Document Delivery Clerk \\ University of Wyoming
}

The authors of the article, "Document Delivery Service," published in C\&RL News, December 1986, pp.704-707, have received a number of inquiries about the service offered by the University of Wyoming Libraries. Document Delivery is funded entirely by an allocation from the indirect cost fund account in the Office of Research and Graduate Studies in the amount of $\$ 20,000-\$ 22,000$ annually. The service provides free retrieval, photocopy, and delivery of libraryowned materials to faculty in order to support research. It is staffed by one full-time clerk and parttime student help and is administratively aligned with Interlibrary Loan. As a response to some of the questions we received, we may draw five conclusions from our sixteen months of service to the faculty:

1) The faculty continue to make extensive use of the service;

2) The budget has been sufficient to meet demand to this point;

3) The service is used to gather information for grant writing and free faculty to concentrate on proposal preparation;

4) Abuse of the service is limited, and faculty, when alerted to abuse, have taken steps to reduce it; and

5) Faculty are supportive of the service and the prospect for future funding is good.

1. Use of the service. One hundred seventy-two faculty members requested and received 11,798 articles, 4,167 microform printouts totalling 91,447 pages, and 352 monographs for use in their research. Faculty from forty-two departments made use of the service, with zoology, pharmacy, English, nursing, biochemistry and accounting department faculty submitting the greatest number of requests.

2. Budget. The first-year budget for Document Delivery was used to equip a work area and hire a full-time person for the January through June period. The balance was used to hire consultants to do collection assessments. The second-year budget was devoted to personnel (full-time and parttime), supplies, and photocopying and microform copying costs. All costs of the service are paid with Document Delivery funds. More part-time help was added during the second year to keep up with demand.
3. How the service is used. Nursing department faculty, for example, make very heavy use of the service. In large part because of Document Delivery, more than twice as many research grant proposals were completed by nursing faculty than were written the year before. Faculty have used Document Delivery to obtain articles to be used in writing grants or in getting papers published and occasionally to release themselves from classrelated library work in order to find time to write grant proposals or papers. One individual said that the service has been so useful to personal research and writing efforts that it is a major factor in this person's decision to stay at the University of Wyoming instead of seeking employment at a higher salary elsewhere. The department uses the service in new faculty recruitment to demonstrate to applicants that the libraries and the university actively support faculty research.

4. Abuse of the service. After the existence of the service became widely known and graduate research assistants were allowed to submit requests on behalf of faculty, we found that Document Delivery was filling some requests for graduate student research as well. The free photocopying was an especially attractive service. Faculty in the few departments where abuse was detected were asked to submit signed faculty requests. Once understood by faculty that the service was for faculty only and that student use jeopardized the service, abuse was curtailed.

5. Future. The service is completing its second year of funding (one and one-half years of operation). The third year of funding is anticipated and continued funding will be sought with the help of faculty. Adjustments and refinements to the service are being made on a regular basis. Problems with copying microforms are being alleviated by the libraries' purchase of new copiers, staff are investigating alternatives to the long photocopied bibliographies being submitted, and minor problems associated with using the Law School Library are being examined. Recordkeeping will be improved with the addition of another microcomputer in the Interlibrary Loan Office. The UW Libraries and faculty are looking forward to continued funding and improvements in the Document Delivery Service.

The Document Delivery Service is an effective 


\section{ACQUISITION PERSPECTIVES}

5. Monographs in continuation and standing orders are given special attention. Your first volume required and all future volumes will be delivered as soon as they become available.

Write or call for details about our reliable standing order service to libraries.

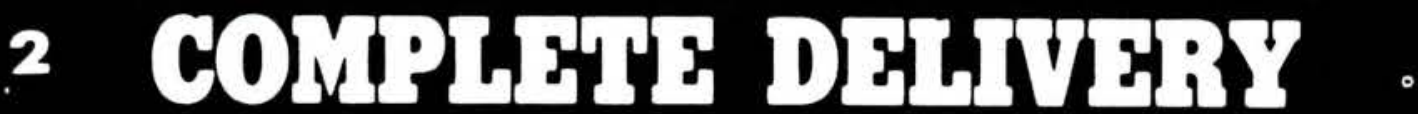

\section{OPAN ORDAR BAPORTS}

4 ICCURATH BOOR DHWVAR?

CALL TOLL-FREE TODAY

1-800-248-1146

In Canada \& Michigan

CALL COLLECT (517) 849-2117

OCLC Vendor No. 17397

SAN $169-3859$
5

STPNDTE

ORD His
BOOK HOUSE BEOULAD ITHES

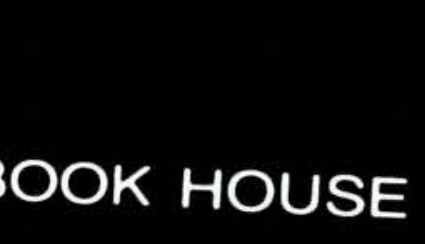

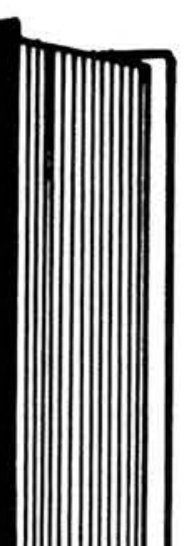


way to meet faculty research needs and to use indirect cost funds to visibly and directly affect individual faculty research projects which generate those indirect cost funds. It provides the libraries with a highly visible service which is available only to faculty and may be used by departments as one more way to attract outstanding new research faculty to the university.

\section{ACRL officers for 1987-88}

\section{The official ACRL election results.}

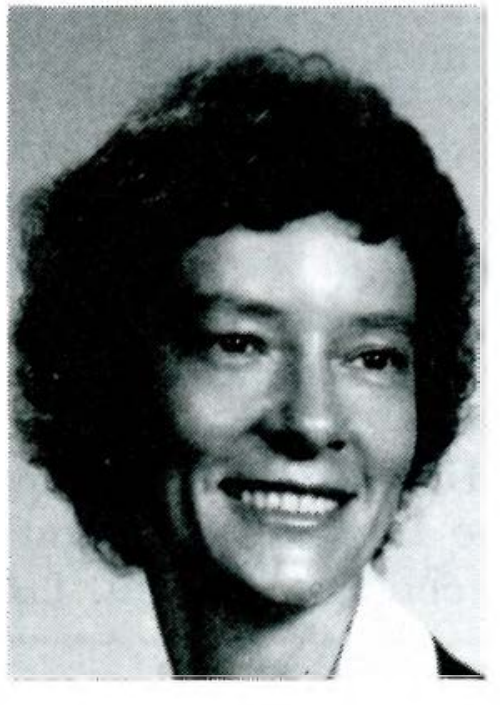

Joanne Euster

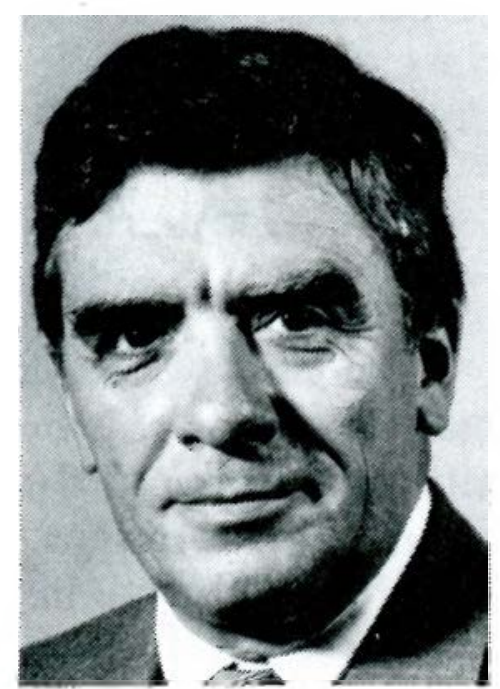

Joseph Boissé
JoAnNe R. Euster, director of libraries at Rutgers, the State University of New Jersey (New Brunswick, NJ 08903), is the fiftieth president of the Association of College and Research Libraries. During her one-year term of office, she will preside over the ACRL Board of Directors and the ACRL Executive Committee. She will chair the ACRL Conference Program Planning Committee for the 1988 Annual Conference in New Orleans and will plan ACRL's major program at the conference.

As president of the division, Euster will represent ACRL on the ALA New Orleans Conference Program Planning Committee and the ALA Planning and Budget Assembly. She will also represent ACRL and ALA in their relations with other organizations. Euster has been very active in ALA and has served as chair of ACRL's Publications Committee from 1982 to 1986 and on the ALA Committee on Standards.

JOSEPH A. BoIsSÉ, university librarian at the Uni- versity of California, Santa Barbara (Santa Barbara, CA 93106), has been elected vicepresident/president-elect of the Association of College and Research Libraries. The 1987 election results showed 1,204 votes for Boissé and 1,166 for Joan Chambers, director of libraries at Colorado State University, Fort Collins, CO 80523.

As vice-president/president-elect of ACRL, Boisse will serve on the ACRL Board of Directors and the ACRL Executive Committee. He will chair the ACRL Conference Program Planning Committee for the 1989 Annual Conference in Dallas. He will represent ACRL on the ALA Appointments Committee and the ALA Conference Program Planning Committee for the 1989 Conference. At the end of the 1988 Annual Conference he will become ACRL's fifty-first president.

Boissé has served on several ACRL committees, including the Legislation, Continuing Education, and Appointments and Nominations Committees. He was a member of the ACRL Task Force on Libraries in Higher Education in 1982-1984 and the LAMA Board of Directors in 1980-1982.

The results of the ACRL elections follow. For each position, the elected candidate is listed first. The number of votes earned by each candidate is given in parentheses.

\section{ACRL Board of Directors}

Director-at-Large (four-year term): PETER MALANCHUK, Chairman, Department of Reference and Bibliography, University of Florida, Gainesville, FL 32611 (1,212); Charles Fineman, Humanities Bibliographer, Northwestern University, Evanston, IL 60201 (982). 